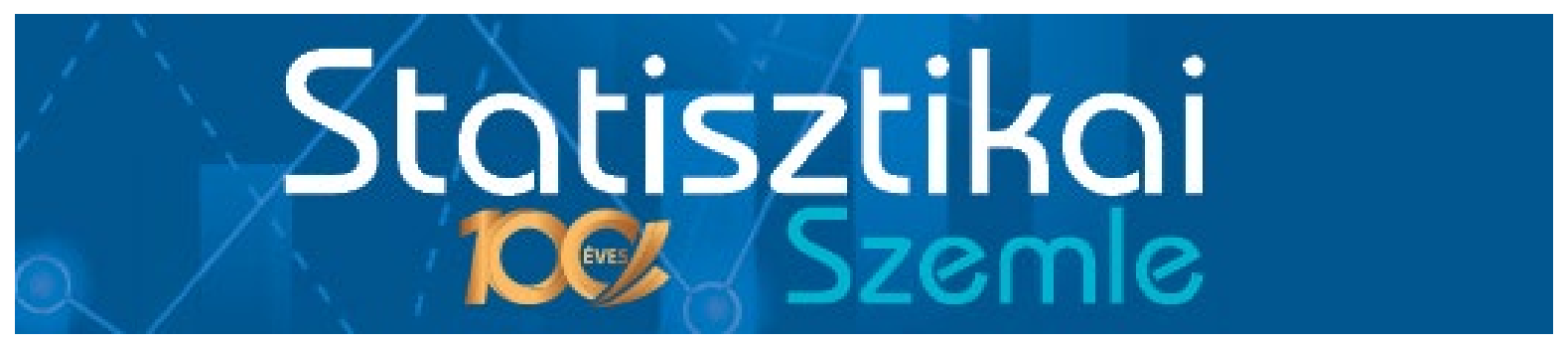

Közzététel: 2022. január 14.

A tanulmány címe:

Hogyan változtatta meg a COVID-19 járvány az emberek életét?

Szerző:

Pomázi István

egyetemi magántanár, ny. szakmai főtanácsadó

E-mail: pomazi.istvan@gmail.com

DOI: https://doi.org/10.20311/stat2022.1.hu0092

Az alábbi feltételek érvényesek minden, a Központi Statisztikai Hivatal (a továbbiakban: KSH) Statisztikai Szemle c. folyóiratában (a továbbiakban: Folyóirat) megjelenő tanulmányra. Felhasználó a tanulmány vagy annak részei felhasználásával egyidejüleg tudomásul veszi a jelen dokumentumban foglalt felhasználási feltételeket, és azokat magára nézve kötelezőnek fogadja el. Tudomásul veszi, hogy a jelen feltételek megszegéséből eredő valamennyi kárért felelősséggel tartozik.

1. A jogszabályi tartalom kivételével a tanulmányok a szerzői jogról szóló 1999. évi LXXVI. törvény (Szjt.) szerint szerzői münek minősülnek. A szerzői jog jogosultja a KSH.

2. A KSH földrajzi és időbeli korlátozás nélküli, nem kizárólagos, nem átadható, térítésmentes felhasználási jogot biztosít a Felhasználó részére a tanulmány vonatkozásában.

3. A felhasználási jog keretében a Felhasználó jogosult a tanulmány:

a) oktatási és kutatási célú felhasználására (nyilvánosságra hozatalára és továbbítására a 4. pontban foglalt kivétellel) a Folyóirat és a szerző(k) feltüntetésével;

b) tartalmáról összefoglaló készítésére az írott és az elektronikus médiában a Folyóirat és a szerző(k) feltüntetésével;

c) részletének idézésére - az átvevő mü jellege és célja által indokolt terjedelemben és az eredetihez híven - a forrás, valamint az ott megjelölt szerző(k) megnevezésével.

4. A Felhasználó nem jogosult a tanulmány továbbértékesítésére, haszonszerzési célú felhasználására. Ez a korlátozás nem érinti a tanulmány felhasználásával előállított, de az Szjt. szerint önálló szerzői münek minősülő mü ilyen célú felhasználását.

5. A tanulmány átdolgozása, újra publikálása tilos.

6. A 3. a)-c.) pontban foglaltak alapján a Folyóiratot és a szerző(ke)t az alábbiak szerint kell feltüntetni:

„Forrás: Statisztikai Szemle c. folyóirat 100. évfolyam 1. számában megjelent, Pomázi István által írt,

'Hogyan változtatta meg a COVID-19 járvány az emberek életét?' című tanulmány (link csatolása)"

7. A Folyóiratban megjelenő tanulmányok kutatói véleményeket tükröznek, amelyek nem esnek szükségképpen egybe a KSH vagy a szerzők által képviselt intézmények hivatalos álláspontjával. 


\title{
Hogyan változtatta meg a COVID-19 járvány az emberek életét?*
}

\section{How has COVID-19 changed people's lives?}

\author{
POMÁZI ISTVÁN \\ egyetemi magántanár, ny. szakmai főtanácsadó \\ E-mail: pomazi.istvan@gmail.com
}

\begin{abstract}
Az OECD (Organisation for Economic Co-operation and Development Gazdasági Együttmüködési és Fejlesztési Szervezet) 60 éve alakult meg, és jelenleg 38 tagországot számlál. Magyarország 1996-ban csatlakozott a kormányközi szervezethez, amely hatalmas statisztikai adatbázist felhasználva végez minden szakpolitikai területen összehasonlító elemzéseket, és ezek alapján fogalmazza meg ajánlásait a tagországok számára.

A 2007-2008-as globális pénzügyi válságot követően az OECD már nemcsak a gazdasági növekedés és a bruttó hazai termék (gross domestic product, GDP) kizárólagosságát hirdeti a jólét (welfare) meghatározásában és mérésében, hanem egyre inkább a jóllétet (well-being) helyezi a társadalmi haladás középpontjába. E fontos témát előtérbe helyezve, 2020 novemberében létrehozták a WISE-t (OECD Centre on Well-being, Inclusion, Sustainability and Equal Opportunity - az OECD Jólléti, Befogadási, Fenntarthatósági és Esélyegyenlőségi Központja), melynek fő feladatai közé tartozik az új adatok előállítása és összehasonlító elemzése, valamint megoldások keresése az emberek jóllétének javítása és az egyenlötlenségek csökkentése érdekében. Emellett fontos célkitüzés a különböző szakpolitikák társadalmi életre és életminőségre gyakorolt hatásainak jobb megértése.

Az OECD a globális koronavírus-járvány 2019. évi kitörése óta valamennyi szakpolitikai területen fö küldetésének tekinti a járvány hatásainak elemzését, a szakpolitikai következtetések levonását és ajánlások megfogalmazását.
\end{abstract}

* OECD [2021]: COVID-19 and Well-being: Life in the Pandemic. Paris.

STATISZTIKAI SZEMLE, 100. ÉVFOLYAM 1. SZÁM 92-95. OLDAL DOI: 10.20311/stat2022.1.hu0092 
Az ismertetett kiadvány a COVID-19 jóllétre gyakorolt hatásait széleskörüen tekinti át a 2020. március és 2021. június közötti tizenöt hónap tapasztalatai alapján, és a "How's life?" (Milyen az élet?) jelentések részeként az OECD által kialakított jólléti keretrendszer szerkezetét követi (ez 11 dimenziót tartalmaz), és holisztikus képet rajzol arról, hogy a járvány miként érintette az emberek életét, a különböző társadalmi csoportokat, valamint milyen hatást gyakorolt az erőforrások készleteire (a természeti, gazdasági, humán és társadalmi tőkére), amelyek a jóllét fenntartásához szükségesek. Ezenkívül a jelentés azt is feltárja, hogy a jóllét „szemüvegén” át miképpen lehet új szakpolitikákat kialakítani és a járványból való kilábalási stratégiákat megtervezni, beleértve a közhivatalok, a társadalmi, üzleti és civil szereplők közötti erösebb stratégiai összehangolást is.

A járvány az emberi jóllét minden területére hatott. A többlethalálozás 2020. március és 2021. május között az OECD országaiban átlagosan 16 százalékot tett ki, amely a születéskor várható élettartamot 7 hónappal csökkentette. A kormányzati támogatások valamelyest segítettek fenntartani az átlagos háztartási jövedelmeket, ennek ellenére három emberből egy komoly pénzügyi nehézségekről számolt be. A kormányzati támogatások valamelyest segítettek fenntartani az átlagos háztartási jövedelmeket, ennek ellenére - egy 25 OECD-országra kiterjedt háztartásipanelfelmérés szerint - az alacsonyabb végzettségüek körében három emberből egy komoly pénzügyi nehézségekről számolt be. A járvány kihatott a lakosság mentális állapotára is, amelynek következtében - 15 ország adatai alapján - minden negyedik embernél a depresszió és szorongás tünetei jelentkeztek. A bevezetett korlátozó intézkedések iskolabezárásokhoz, fizetés nélküli otthoni gondozáshoz és egyre több családi erőszakhoz vezettek.

A jólléttel összefüggő egyes terhelések csökkentek a járvány korai szakaszaiban (például jelentősen visszaesett a légszennyezés és a széndioxid-kibocsátás, lényegesen kevesebb lett a halálos kimenetelü közlekedési balesetek száma, nőtt a bizalom a kormányzati intézkedések irányában), ugyanakkor mindezek a korlátozó intézkedések feloldását és lazítását követően a korábbi „normális” viszonyokhoz való visszatérés jeleit mutatják.

A magányosság, a társadalomtól való eltávolodás érzése szintén megfigyelhető volt a vizsgált időszakban. A járvány a legerőteljesebben azokat az embereket érintette, akik egyébként is nehéz körülmények között éltek. A hátrányok halmozódtak, és ezt sokszor a rendelkezésre álló adatokból nehéz pontosan látni, ezért gyakran alulbecsültek bizonyos csoportok esetében a jólléttel kapcsolatos felmérések eredményei. Az idősebbek sokkal jobban szenvedtek a fertőzés következményeitől, és körükben magasabb volt a halálozási ráta, valamint elövigyázatossági okokból elsősorban ők csökkentették társadalmi kapcsolataikat. Ezzel szemben a fiatalabb felnőttek körében lehetett a leginkább tapasztalni a mentális betegségek előfordulását, 
a társadalmi kapcsolatok beszükülését, a munkahely elvesztésétől való félelmet és az általános bizonytalanságot.

Az etnikum kapcsolata a jóléttel nagyon összetett kérdés: számos társadalmigazdasági tényező, az élet- és munkakörülmények, a rasszizmus és a diszkrimináció mélyen gyökerező formái okozhatják, hogy az egyes csoportokat tekintve a járvány eltérő hatásai tapasztalhatók. Szinte a teljes népességnek romlott a mentális egészségi állapota, azonban a kisebbségi csoportokat még súlyosabban érintette a járvány.

Az átlagos jólléti következmények eltérő képet mutattak a nemek és a különböző háztartások között is. A többlethalálozás magasabb volt a férfiak, mint a nők esetében, a nők hosszabb ideig szenvedtek a vírus tüneteitől, és gyakrabban számoltak be mentális problémákról, magányosságról. Ugyanakkor a nők a frontvonalban voltak a járvány alatti ápolásban, akár a napi munkájukból adódóan, akár az otthoni gondozás terén.

A lakáskörülmények és az együttélés a jóllét új dimenziójára világított rá a járvány ideje alatt. Az élettel való elégedettség különösen a gyermekes párok esetében esett jelentős mértékben, míg a teljes népességhez viszonyítva a gyermek nélküli párok és az egyedülállók között mintegy kétszerese volt azok száma, akik magányosnak érezték magukat.

Az, hogy az embereknek volt-e munkája és hol dolgoztak, szintén befolyást gyakorolt a koronavírusnak és a válság hatásainak való kitettségre. Az alulfoglalkoztatottság 2020-ban az OECD-országokban elérte a 17 százalékot, és a 15-29 évesek korcsoportjában 13 százalékot tett ki azoknak az aránya, akik nem dolgoztak, nem tanultak és nem vettek részt valamilyen képzésben, eltörölve ezzel a 2007-2008-as válság óta elért eredményeket.

A telemunka (home office) segített az embereknek munkahelyük megőrzésében, különösen a jól fizetett és magas végzettséget igénylő csoportok körében, de ez a lehetőség nem volt választható a munkavállalók többsége számára.

A járvány gyermekekre és fiatalokra gyakorolt hatásai mellett a természeti, gazdasági, humán és társadalmi tőkében okozott károk következményei hosszú távon is nyomot hagynak a társadalom jóllétében. A múlt jobb visszaépítése (building back better) azt jelenti, hogy válaszokat kell adni a klíma- és biodiverzitás- (biológiai sokféleség-) válságra, amely a jóllétet fenyegeti, és újra kell építeni a humán és társadalmi infrastruktúrát.

A járvány által okozott megterhelések sok ember számára jövőbeni egészségi kockázatokat jelentettek, mint például súlygyarapodást és megnövekedett alkoholfogyasztást. Az egészségügyi intézményekbe vetett bizalom fontos reziliencia (ellenálló képesség) tényező volt a COVID-19 elleni küzdelemben. Ugyanakkor az egyes kormányok által élvezett korábbi bizalom az idő elteltével csökkenni kezdett.

2021 elején háromból egy ember érezte úgy, hogy ki van rekesztve a társadalomból, és 12 országban a felnőttek többsége úgy nyilatkozott, hogy országa jobban

STATISZTIKAI SZEMLE, 100. ÉVFOLYAM 1. SZÁM 92-95. OLDAL DOI: 10.20311/stat2022.1.hu0092 
megosztott, mint a koronavírus-járvány kitörése előtt volt. A felmérések szerint a fiatalok és a nők továbbra is alulreprezentáltak voltak a döntéshozatalban.

A koronavírus-járvány első 15 hónapja alatt a jóllétre gyakorolt hatások feltárása a gyors változások következtében egyfajta mozgó célpontot jelentett. Megnövekedtek a gyors információ- és adatszolgáltatás iránti igények, gyakorta nehézkessé vált az adatgyüjtés, és új kihívásokat teremtett az adatminőség biztosítása. Egyes OECD-országok statisztikai hivatalai jelentős újításokat - nagyobb gyakoriságú háztartási, internetalapú felméréseket és kísérleti időmérleg mintavételeket - vezettek be. Ezek fontos tapasztalatokkal jártak a különböző módszerek standardizálása és a nemzetközi statisztikai együttmüködés továbbfejlesztése szempontjából.

A jóllét szinte minden dimenzióját részletesen elemző kötet egyértelmüen arra világít rá: ahogy a kormányok elmozdulnak a mindenképpen szükségesnek tekintett vészhelyzeti támogatástól a kilábalás ösztönzését célzó intézkedések irányába, a hangsúlyt az emberek jóllétének javítására kell helyezniük. Elsődleges célul a háztartások foglalkoztatási és pénzügyi biztonságának növelését kell kitüzni, különösen a koronavírus okozta válság által leginkább sújtott csoportok (fiatalok, nők és alacsony képzettségúek) esetében. Az életszínvonal emelését és az esélyegyenlőség javítását célzó intézkedéseket össze kell kapcsolni a gazdaság zöldítésével, a klíma- és biodiverzitás-válság, valamint a pandémia kezelésével. Ezt csak rendszerszintű gondolkodáson alapuló döntéshozatallal és a különböző szakpolitikák összehangolásával lehet sikeresen megvalósítani, ezáltal erősítve a társadalom ellenálló képességét a jövőbeni külső és belső sokkokkal szemben. 